einstein

Official Publication of the Instituto Israelita

de Ensino e Pesquisa Albert Einstein

ISSN: 1679-4508 | e-ISSN: 2317-6385

\title{
Hereditary angioedema: how to approach it at the emergency department?
}

\author{
Angioedema hereditário: como abordar na emergência?
}

\author{
Faradiba Sarquis Serpa', Eli Mansour², Marcelo Vivolo Aun³, Pedro Giavina-Bianchi', \\ Herberto José Chong Neto ${ }^{5}$, Luisa Karla Arruda ${ }^{6}$, Regis Albuquerque Campos ${ }^{7}$, \\ Antônio Abílio Motta ${ }^{4}$, Eliana Toledo ${ }^{8}$, Anete Sevciovic Grumach ${ }^{9}$, Solange Oliveira Rodrigues Valle ${ }^{10}$ \\ ${ }^{1}$ Escola Superior de Ciências, Santa Casa de Misericórdia de Vitória, Vitória, ES, Brazil. \\ ${ }^{2}$ Faculdade de Ciências Médicas, Universidade Estadual de Campinas, Campinas, SP, Brazil. \\ ${ }^{3}$ Faculdade Israelita de Ciências da Saúde Albert Einstein, Hospital Israelita Albert Einstein, São Paulo, SP, Brazil. \\ ${ }^{4}$ Faculdade de Medicina, Universidade de São Paulo, São Paulo, SP, Brazil. \\ ${ }^{5}$ Universidade Federal do Paraná, Curitiba, PR, Brazil. \\ ${ }^{6}$ Faculdade de Medicina de Ribeirão Preto, Universidade de São Paulo, Ribeirão Preto, SP, Brazil. \\ ${ }^{7}$ Faculdade de Medicina, Universidade Federal da Bahia, Salvador, BA, Brazil. \\ ${ }^{8}$ Faculdade de Medicina de São José do Rio Preto, São José do Rio Preto, SP, Brazil. \\ ${ }^{9}$ Faculdade de Medicina do ABC, Santo André, SP, Brazil. \\ ${ }^{10}$ Universidade Federal do Rio de Janeiro, Rio de Janeiro, RJ, Brazil.
}

DOI: 10.31744/einstein_journal/2021RW5498

\section{ABSTRACT}

Angioedema attacks are common causes of emergency care, and due to the potential for severity, it is important that professionals who work in these services know their causes and management. The mechanisms involved in angioedema without urticaria may be histamine- or bradykininmediated. The most common causes of histamine-mediated angioedema are foods, medications, insect sting and idiopathic. When the mediator is bradykinin, the triggers are angiotensinconverting enzyme inhibitors and factors related to acquired angioedema with deficiency of C1inhibitor or hereditary angioedema, which are less common, but very important because of the possibility of fatal outcome. Hereditary angioedema is a rare disease characterized by attacks of edema that affect the subcutaneous tissue and mucous membranes of various organs, manifesting mainly by angioedema and abdominal pain. This type of angioedema does not respond to the usual treatment with epinephrine, antihistamines and corticosteroids. Thus, if not identified and treated appropriately, these patients have an estimated risk of mortality from laryngeal edema of $25 \%$ to $40 \%$. Hereditary angioedema treatment has changed dramatically in recent years with the development of new and efficient drugs for attack management: plasma-derived C1 inhibitor, recombinant human $\mathrm{C} 1$-inhibitor, bradykinin B2 receptor antagonist (icatibant), and the kallikrein inhibitor (ecallantide). In Brazil, plasma-derived C1 inhibitor and icatibant have already been approved for use. Proper management of these patients in the emergency department avoids unnecessary surgery and, especially, fatal outcomes.

Keywords: Angioedema; Angioedemas, hereditary; Emergencies; C1-inhibitor; Abdominal pain; Laryngeal edema; Asphyxia; Bradykinin

\section{RESUMO}

As crises de angioedema são causas comuns de atendimentos nas emergências, e devido ao potencial de gravidade, é importante que os profissionais que atuam nesses serviços conheçam suas causas e abordagem. Os mecanismos envolvidos no angioedema sem urticas podem ser histaminérgicos ou mediados por bradicinina. As causas mais comuns de angioedema mediado por histamina são alimentos, medicamentos, ferroada de insetos e idiopática. Quando o mediador é a bradicinina, os desencadeantes são os inibidores da enzima conversora de angiotensina e fatores relacionados ao angioedema adquirido com deficiência do inibidor de C1 ou angioedema 
hereditário que são menos comuns, mas muito importantes pela possibilidade de desfecho fatal. 0 angioedema hereditário é uma doença rara, caracterizada por crises de edema que acometem 0 tecido subcutâneo e mucosas de vários órgãos, manifestando-se principalmente por crises de angioedema e dor abdominal. Esse tipo de angioedema não responde ao tratamento usual com adrenalina, anti-histamínicos e corticosteroides. Assim, se não identificados e tratados adequadamente, esses pacientes têm risco de mortalidade por edema de laringe estimado em $25 \%$ a $40 \%$. 0 tratamento do angioedema hereditário mudou drasticamente nos últimos anos, com o desenvolvimento de novos e eficientes fármacos para as crises: inibidor de $\mathrm{C} 1$ derivado de plasma, inibidor de C1 recombinante humano, antagonista do receptor B2 da bradicinina (icatibanto) e 0 inibidor da calicreína (ecalantide). No Brasil, até o momento, estão liberados para uso o inibidor de C1 derivado de plasma e o icatibanto. 0 manejo correto desses pacientes na emergência evita cirurgias desnecessárias e, principalmente, desfechos fatais.

Descritores: Angioedema; Angioedemas hereditários; Emergências; Inibidor de C1; Dor abdominal; Edema laríngeo; Asfixia; Bradicinina

\section{INTRODUCTION}

Angioedema is characterized by non-inflammatory, localized, asymmetric, disfiguring, and self-limited swelling of the deep dermis, subcutaneous, and/or submucosal tissue, resulting from vasodilation and an increase in vascular permeability. ${ }^{(1)}$

Due to potential severity, especially when angioedema affects the airways, the therapeutic approach in emergency department is often initiated soon after admission, before taking the medical history and possible identification of the etiology. However, the recognition and differentiation of the different etiologies and pathogenesis of angioedema are important for an efficacious treatment in the emergency department. ${ }^{(2,3)}$

The mechanism involved in angioedema without urticaria can be mediated by histamine or bradykinin. The most common causes of histaminergic angioedema are food, medication, insect bites, and idiopathic. In bradykinin-mediated angioedema, the most frequent triggers are angiotensin-converting enzyme inhibitors (ACEi) and factors related to hereditary angioedema (HAE) or acquired angioedema (AAE). Although less common, AAE and HAE are relevant because of the possibility of a fatal outcome, if not properly treated.(4)

Hereditary angioedema is a rare, potentially fatal, and still underdiagnosed disease. Its attacks can affect both the dermis and subcutaneous, as well as internal organs - predominantly the gastrointestinal tract and upper airways - the most feared outcome being laryngeal angioedema. It is estimated that $25 \%$ to $40 \%$ of HAE attacks lead to death by asphyxia, when untreated. ${ }^{(5)}$ Intestinal wall edema is frequent and disabling, and abdominal pain may be the only manifestation during an attack. Abdominal angioedema attack may be misdiagnosis of acute abdomen leading to unnecessary surgery. ${ }^{(6)}$

In the emergency department, HAE attacks can be mistaken with other types of angioedema, mainly histaminergic. A Brazilian study showed that $29 \%$ of patients with HAE reported deaths in family members due to asphyxia. ${ }^{(7)}$ In the cases studied by Bork et al., ${ }^{(5)}$ the cause of death in one third of patients was asphyxia, those with no confirmed diagnosis being most at risk.

Data from the United States show that approximately 110 thousand emergency department visits per year are due to HAE or AAE. These patients have a higher hospital admission rate than those treated for allergycaused angioedema. ${ }^{(8)}$ In an Italian study, $0.37 \%$ of patients admitted to the emergency department during a six month period presented with angioedema of varyng causes. ${ }^{(9)}$ In Canada, $0.1 \%$ of emergency care was due to angioedema of different etiologies, and more than one third of patients reported previous visits for the same cause. ${ }^{(10)}$ No data is avaiable in Brazil on the number of visits to emergency department caused by angioedema attacks.

There is an urgent need to inform health professionals, especially those working in emergency department about HAE as well as relevant aspects for the care of angioedema attacks. The authors aim to address these questions.

\section{METHODS}

We evaluated publications that addressed the topic HAE through revision of MEDLINE ${ }^{\circledR}$ (PubMed $^{\circledR}$ ), Cochrane, and Scientific Electronic Library Online (SciELO) databases, and considered the consensus and guidelines previously published, with the purpose of using practices already approved by experts on the subject, including Brazil, over the last 10 years. The Health Sciences Descriptors (DeCS) "hereditary angioedema", "emergency" and "bradykinin," the Boolean operator "AND" and their correspondents in Portuguese were used.

\section{Classification of angioedema without urticaria}

Angioedema can be classified in relation to the vasoactive mediator causing the edema, i.e., histamine, or bradykinin. This classification allows the identification of the type of angioedema and its appropriate treatment $^{(3)}$ (Figure 1). 
Histaminergic angioedema is the most common. It progresses rapidly, ${ }^{(4)}$ is generally associated with urticaria, and occurs due to mast cell degranulation, mediated or not by immunoglobulin $\mathrm{E}$ ( $\mathrm{IgE}$ ), or by alteration in arachidonic acid metabolism, typified by cases induced by nonsteroidal anti-inflammatory drugs (NSAIDs)..$^{(11)}$

Bradykinin-mediated cases are clinically characterized by the absence of urticaria and include HAE, C1-inhibitor AAE (C1-INH), and drug-induced: ACEi, angiotensin II receptor blocker, and glyptins.

There are two subtypes of HAE: due to deficiency of C1-inhibitor (HAE-C1-INH) and with normal C1-INH (HAE with normal C1-INH). ${ }^{(1,12)}$ The genetic inheritance of HAE-C1-INH is autosomal dominant, resulting from mutations in the SERPING1 gene, which encodes a serinoprotease, C1-INH, with several sites of action. Such mutations result in quantitative and/or functional deficiency of $\mathrm{C} 1-\mathrm{INH}$, which causes the exaggerated production of bradykinin, with a consequent increase in vascular permeability and the onset of angioedema. Hereditary angioedema with normal C1-INH is associated with other mutations, and also lead to bradykinin overproduction. ${ }^{(13,14)}$ Cases of coagulation factor XII (FXII) mutation are the most common. ${ }^{(13,14)}$ Other recently described mutations occur in plasminogen (HAE-PLG), ${ }^{(15)}$ angiopoietin-1 (HAE-ANGPT1), ${ }^{(13)}$ and kininogen-1 (KNG1) genes. ${ }^{(16)}$

AAE-C1-INH results from C1-INH consumption, and the most common causes being lymphoproliferative and autoimmune diseases. ${ }^{(17)}$ The clinical picture is similar to HAE, but the onset of symptoms is later, and the family history is negative. ${ }^{(1,12)}$

Antihypertensive agents in the ACEi group represent $0.1 \%$ to $0.5 \%$ of angioedema cases seen in emergency department.$^{(17)}$ Attacks can occur regardless of the length of use, and the ACEi most frequently related to the occurrence of angioedema are captopril, enalapril, and lisinopril. ${ }^{(18)}$ Medications of the group of gliptins, sitagliptin, vildagliptin, saxagliptin, alogliptin, and linagliptin, used to treat type 2 diabetes mellitus, are also potential triggers of angioedema. These drugs inhibit the enzyme dipeptidyl peptidase 4 (DPP4i), which is important in the degradation of bradykinin and substance P. ${ }^{(19)}$

Data on the prevalence of bradykinin-mediated angioedema are scarce, and studies show that ACEi angioedema is more common than HAE, and the latter being more common than AAE-C1-INH. ${ }^{(20)}$

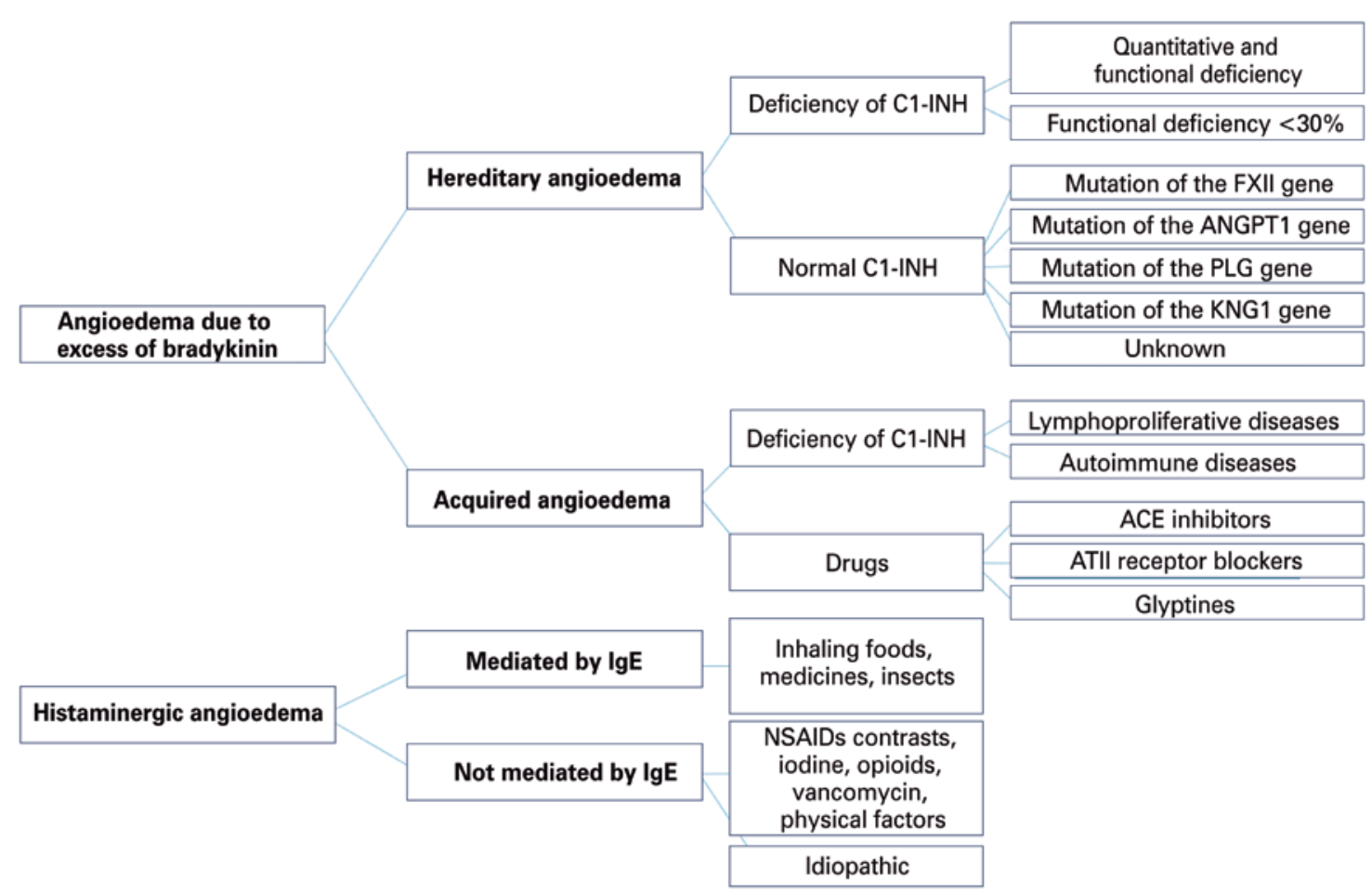

C1-INH: C1 inhibitor; FXII: coagulation factor XII; ANGPT1: angiopoietin-1; PLG: plasminogen; KNG1: kininogen 1; ACE: angiotensin-converting enzyme; ATII: angiotensin II; lgE: immunoglobulin E; NSAIDs: non-steroid anti-inflammatory drugs. Figure 1. Classification of angioedema in terms of associated mechanisms and defects 
Some clinical characteristics, such as age of onset of symptoms, positive family history, the association of urticaria, location of the attack, and speed of onset and progression, permit differentiating five main phenotypes of angioedema (Table 1).

\section{Pathophysiology of bradykinin-mediated angioedema}

Bradykinin is the primary mediator in AAE and HAE with quantitative or functional deficiency of C1-INH. C1-INH regulates several proteins of the complement, contact, coagulation, and fibrinolysis systems. The activation of the contact system begins with the activated FXII that converts pre-kallikrein into kallikrein; this, in turn, cleaves the high molecular weight kininogen (HK), leading to the release of bradykinin. This kinin binds to its B2 receptor, constitutively expressed in endothelial cells, and interferes with endothelial junctions, increasing vascular permeability and causing angioedema. In C1-INH deficiency, the lack of control of the contact system activation is more relevant to the release of bradykinin. On the other hand, by activation of the complement system, the plasma C4 levels decrease due to lack of C1-INH, and the dosage of $\mathrm{C} 4$ is used as a screening test for $\operatorname{HAE}^{(1,22)}$ (Figure 2).

In HAE with normal C1-INH, the mutations in FXII result in greater activation of FXII by plasmin, generating the activated factor XII, which acts on pre-

Table 1. Clinical characteristics of the main phenotypes of angioedema

\begin{tabular}{|c|c|c|c|c|c|c|}
\hline \multirow{2}{*}{$\begin{array}{l}\text { Clinical } \\
\text { characteristics }\end{array}$} & \multicolumn{6}{|c|}{ Main phenotypes of angioedema } \\
\hline & $\begin{array}{c}\text { Histaminergic or allergic } \\
\text { angioedema }\end{array}$ & $\begin{array}{l}\text { HAE with C1-INH } \\
\text { deficiency }\end{array}$ & HAE with normal C1-INH & AAE-C1-INH & ACEi & Idiopathic \\
\hline Age of onset & Variable & Childhood & Adolescent/adult & Adult & Adult & Variable \\
\hline Family history & Atopy (?) & $75 \%$ cases & Variable & No & No & No \\
\hline Sex predilection & No & No & Female & No & No & No \\
\hline Associated urticaria & Yes/no & No & No & No & No & Yes/no \\
\hline Attack site & Lips, eyes, tongue, and larynx & $\begin{array}{l}\text { Face, tongue, larynx, genitals, } \\
\text { limbs, and abdomen }\end{array}$ & $\begin{array}{l}\text { Face, tongue, larynx, genitals, } \\
\text { limbs, and abdomen }\end{array}$ & $\begin{array}{c}\text { Face, tongue, larynx, } \\
\text { genitals, limbs, and } \\
\text { abdomen }\end{array}$ & $\begin{array}{l}\text { Face, tongue, and } \\
\text { larynx }\end{array}$ & $\begin{array}{l}\text { Lips, eyes, } \\
\text { tongue, and } \\
\text { larynx }\end{array}$ \\
\hline Onset of attack & Rapid (up to 1 hour) & Slow and gradual (hours) & Slow and gradual (hours) & $\begin{array}{l}\text { Slow and gradual } \\
\text { (hours) }\end{array}$ & $\begin{array}{l}\text { Slow and gradual } \\
\text { (hours) }\end{array}$ & Variable \\
\hline
\end{tabular}

Source: adapted from Moellman JJ, Bernstein JA, Lindsell C, Banerii A, Busse PJ, Camargo CA Jr, Collins SP, Craig TJ, Lumry WR, Nowak R, Pines JM, Raja AS, Riedl M, Ward MJ, Zuraw BL, Diercks D, Hiestand B, Campbell RL, Schneider S, Sinert

R; American College of Allergy, Asthma \& Immunology (ACAAl); Society for Academic Emergency Medicine (SAEM). A consensus parameter for the evaluation and management of angioedema in the emergency department. Acad Emerg Med. 2014:21(4):469-84.1217

HAE: hereditary angioedema; C1-INH: C1 inhibitor; AAE-C1-INH: acquired angioedema with deficiency of C1-inhibitor; ACEi: angiotensin enzyme converter inhibitor.
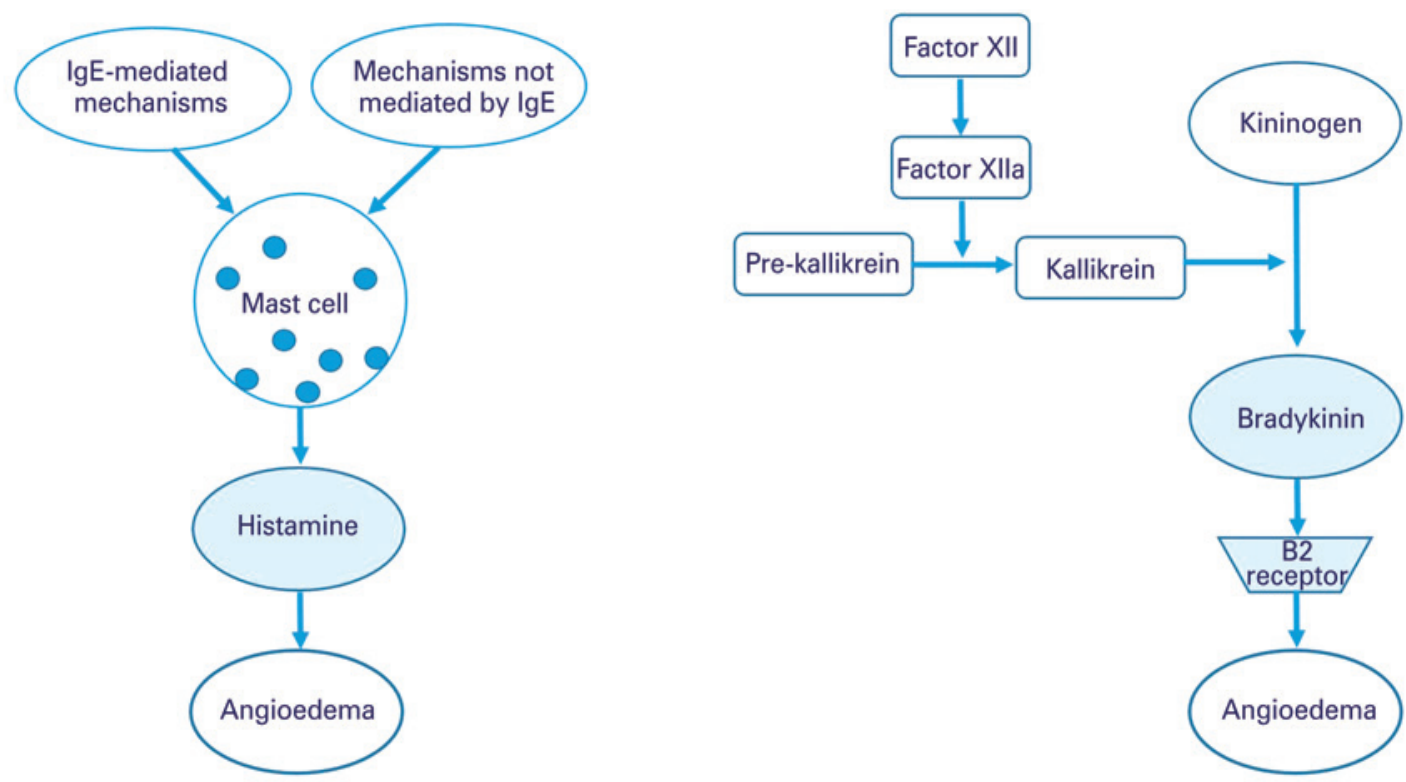

Source: adapted from Bernstein JA, Cremonesi P, Hoffmann TK, Hollingsworth J. Angioedema in the emergency department: a practical guide to differential diagnosis and management. Int J Emerg Med. 2017; 10(1):15. Review.3 IgE: immunoglobulin E; Factor Xlla: activated factor XII; B2 receptor B2: bradikinin receptor.

Figure 2. Pathophysiology of $(A)$ histamine-mediated and $(B)$ bradykinin-mediated angioedema, without urticaria 
kallikrein. ${ }^{(13,14)}$ Thus, FXII mutant activates rapidly after cleavage by plasmin and escapes from C1-INH inhibition. In cases of HAE with mutations in PLG, ${ }^{(15)}$ ANGPT1, ${ }^{(13)}$ or KNG1 genes, ${ }^{(16)}$ other mechanisms are involved. The PLG, eg., is a circulating zymogen, which is converted into the active plasmin enzyme by cleavage of a peptide bond. Plasmin, the main enzyme of fibrinolysis seems to be involved in the pathogenesis of HAE with normal C1-INH, but the role of the fibrinolytic system in HAE has yet to be fully clarified. ${ }^{(15)}$ In case of mutations in the ANGPT1 gene, the loss of protein function is described, with consequent reduction in the angiopoietin-1 receptor activation capacity, expressed in endothelial cells. This, in turn, would influence vascular permeability. ${ }^{(13)}$ In KNG1 gene mutation, an aberrant bradykinin formation occurs, with a longer half-life and, consequently, more active. ${ }^{(16)}$

\section{Clinical and laboratory diagnosis}

When treating patients with angioedema, a detailed medical history, physical examination, and response to conventional treatment with antihistamines (anti-H1), corticosteroids (EC), and epinephrine may indicate the possible etiology.

The presence of urticaria associated with angioedema, both in the current episode and in previous attacks, strongly suggests histaminergic angioedema. ${ }^{(17)}$ This type of angioedema evolves rapidly, ${ }^{(6)}$ and the most common triggers being medication, food, insect venom, physical (heat, cold, and pressure), and even idiopathic factors. In these situations, the removal of the trigger and conventional treatment are effective. ${ }^{(17)}$

When other organs or systems are involved, configuring anaphylaxis, the serum tryptase dosage may corroborate this hypothesis. This test is generally not available in the Brazilian emergency departments, and the delay for the result does not help assistance in the emergency setting. High level of tryptase during the attack will confirm degranulation of mast cells. On the other hand, the normal dosage of tryptase during the attack does not exclude anaphylaxis. ${ }^{(21)}$ High tryptase does not occur in bradykinin-induced angioedema, such as HAE, AAE-C1-INH, or ACEi-induced.

Although angioedema attacks induced by ACEi, AAE-C1-INH, and HAE, all mediated by bradykinin, usually take hours to become full blown, there are reports of sudden events. ${ }^{(21)}$ In addition, they do not present associated urticaria and do not respond to conventional treatment. ${ }^{(1,17)}$
The diagnosis of HAE is generally not made in emergency department. Diagnosis requires clinical data such as family history of angioedema, edema persisting for 3 to 5 days, no response to conventional treatment, recurrent airway edema, and abdominal pain episodes with no apparent cause, sometimes with a history of unnecessary abdominal surgeries. ${ }^{(21)}$ In some cases, prodrome signs and symptoms may occur, such as erythema marginatum, characterized by serpinginous erythematous and non-pruritic lesions, which may be confuses with urticaria. ${ }^{(1)} \mathrm{A}$ family history of HAE is an important warning sign, but is absent in approximately $25 \%$ of cases. ${ }^{(17)}$

Another relevant aspect of women with HAE is the higher frequency and/or severity of attacks in periods of a higher estrogen level, either endogenous (menstrual cycle, pregnancy), or under exogenous administration (contraceptives or hormone replacement) among women. ${ }^{(14)}$ Hereditary angioedema with normal C1INH levels is more associated with estrogen, being even more frequent in women. ${ }^{(14)}$

In patients with no other cause of angioedema, but who present any of these indicators, a diagnosis of $\mathrm{HAE}$ should be presumed, especially if there is no clinical response to conventional treatment with epinephrin, anti-H1, and CE. ${ }^{(17)}$

The diagnosis of HAE C1-INH is confirmed by quantitative and/or functional evaluation of C1-INH. Laboratory tests are often not available for diagnosis in the emergency department. Nevertheless, the dosage of $\mathrm{C} 4$ during the attack may contribute to the diagnosis. It is estimated that almost $100 \%$ of these patients have reduced $\mathrm{C} 4$ levels during the attack, so, if the level of $\mathrm{C} 4$ is normal HAE C1-INH can be ruled out. ${ }^{(21)}$

AAE-C1-INH can be differentiated from HAE-C1$\mathrm{INH}$ as the former, in most cases has low levels of $\mathrm{C} 1 \mathrm{q}$ concentration, in addition to the reduction of $\mathrm{C} 4$, and quantitative and functional C1-INH.

\section{Warning signs for hereditary angioedema}

Grumach et al.,(23) elected the main warning signs for HAE, based on pathophysiology, signs, and symptoms, laboratory tests, and response to specific therapies. To facilitate memorization, the signs were listed in alphabetical order and are called the $\mathrm{ABC}$ of angioedema. ${ }^{(23)}$

With the same objective, the Brazilian Group for the Study of Hereditary Angioedema (Gebraeh) created a mnemonic rule with the warning signs for diagnosis of HAE: HAAAAE. ${ }^{(1)}$ All these signs are listed in table 2.(1) 
Table 2. Warning signs of hereditary angioedema

\begin{tabular}{lc}
\hline \multicolumn{1}{c}{ HAAAAE $^{(\mathbf{1})}$} & ABC of angioedema \\
\hline Hereditary & Angioedema \\
\hline Angioedema [recurrent] & Bradykinin \\
Abdominal pain & C1 inhibitor \\
Absence of urticaria & Triggers \\
Antihistamines with no effect & Epinephrine with no response \\
Estrogen association & Affected family members \\
& Gastrointestinal and/or edema of the glottis \\
\hline
\end{tabular}

Source: Giavina-Bianchi P, Arruda LK, Aun MV, Campos RA, Chong-Neto HJ, Constantino-Silva RN, et al. Diretrizes brasileiras para o diagnóstico e tratamento do angioedema hereditário - 2017. Ara Asma Alerg Imunol. 2017;1(1):23-48; Grumach AS, Ferraroni N, Olivares MM, López-Serrano MC, Bygum A. An ABC of the warning signs of hereditary angioedema. Int Arch Allergy Immunol. 2017;174(1):1-6. Review.23

\section{Triggers for hereditary angioedema attacks}

Hereditary angioedema attacks can be spontaneous or triggered by factors identified by means of a detailed medical history. The following have been described as triggers: trauma, stress, infection, surgical and dental procedures, menses, gestation, alcohol consumption, extreme change in temperature, physical exercise, use of ACEi, exposure to estrogen, among others. ${ }^{(1)}$ Identification of the triggering factor may contribute towards the diagnosis and future follow-up.

\section{Treatment of a hereditary angioedema attack}

The first step when approaching a patient with a HAE attack affecting the airways, tongue, and/or uvula is to keep the airway patent. In unstable patients, with imminent risk of asphyxia, orotracheal intubation (OTI) should not be delayed ${ }^{(21)}$ (Figure 3). It is important to emphasize that in the initial phase of airway obstruction, no drop in oxygen saturation is observed. Emergency room monitoring is indicated and, if cases of hypotension or dehydration, fluid replacement must be initiated. ${ }^{(24)}$

Treatment of an attack in a patient diagnosed with HAE may vary according to the severity and location of the attack, and requires the use of drugs that act by preventing the action of bradykinin in endothelial cells, or increasing levels of C1-INH, and, consequently, reducing bradykinin levels ${ }^{(1)}$ (Figure 4).

Pharmacological treatment has drastically changed in recent years, with the introduction of new and efficient drugs for management of attacks. There are four groups of drugs available: plasma-derived C1inhibitor concentrate (pd C1-INH), recombinant human C1-inhibitor (Rh C1-INH), bradykinin B2 receptor antagonist (icatibant), and kallikrein inhibitor (ecalantide). ${ }^{(24-26)}$ In Brazil, so far, there are two products approved by the National Health
Surveillance Agency (ANVISA - Agência Nacional de Vigilância Sanitária) pdC1-INH (Berinert $\left.{ }^{\circledR}\right)$ and icatibant (Firazyr $\left.^{\oplus}\right)^{(1,27,28)}$ (Table 3).

C1-INH concentrates for intravenous use have been shown to be efficacious and safe in the treatment, both of children and adults, of all forms of HAE attacks due to C1-INH deficiency. ${ }^{(25,29,30)}$ Berinert $^{\circledR}$, approved in Brazil, is indicated for intravenous administration at a dose of $20 \mathrm{IU} / \mathrm{kg}$, regardless of the severity of the attack. ${ }^{(29)}$ Another concentrate of nano-filtrated pdC1INH $\left(\right.$ Cinryze $\left.^{\circledR}\right)$, has been used in fixed doses (500IU or $1,000 \mathrm{IU}$ ), in lower severity attacks, such as angioedema of limbs and abdominal pain episodes. ${ }^{(31)}$ However, there is evidence that fixed doses may not be sufficient to control the attacks, and that the $20 \mathrm{IU} / \mathrm{kg}$ dose is more effective. Bork et al., ${ }^{(31)}$ observed that more than $60 \%$ of patients with a laryngeal edema who received fixed doses of C1-INH concentrate required another dose of the drug.

The recombinant human C1-INH (Ruconest ${ }^{\circledR}$ ) is obtained from the purification of transgenic rabbit milk. Studies have demonstrated its efficacy and safety, with no adverse thrombotic events, though it should be used with care in those with allergy to rabbits. ${ }^{(26)}$ It is not available in Brazil, and the established dose is from $60 \mathrm{IU}$ to $100 \mathrm{IU}$ per $\mathrm{kg}$ of body weight, per dose.

Icatibant $\left(\mathrm{Firazyr}^{\circledast}\right)$ is a synthetic molecule, similar to bradykinin, and acts as a competitive and selective antagonist to the bradykinin $\mathrm{B} 2$ receptor. The safety and efficacy of icatibant have been demonstrated in three clinical trials - phases I, II, and III. ${ }^{(32,33)}$ Hereditary angioedema attacks are resolved more quickly with the early, rather than later use of icatibant, therefore, administration is recommended in the first 6 hours after onset of symptoms. ${ }^{\left({ }^{(3)}\right)}$ It is licensed in Brazil, including for administration at home. Home use is safe, and patients report only erythema and pain at the injection site, with spontaneous resolution. ${ }^{(35)}$ The recommended dose is $30 \mathrm{mg}$ for adults and $0.4 \mathrm{mg} / \mathrm{kg}$ in the age range of 2 to 17 years, subcutaneously, exclusively in the abdominal region. Additional injections may be administered every 6 hours, up to a maximum of three injections in 24 hours. ${ }^{(32)}$

The fourth class of drugs to treat attacks is kallikrein inhibitors, such as Ecallantide (Kalbitor ${ }^{\circledR}$ ), approved for use in the United States and not available in Brazil. The recommended dose is $30 \mathrm{mg}$ subcutaneously, but it is not approved for home administration, since anaphylaxis has been observed in approximately $3 \%$ of patients. ${ }^{(3)}$ To date, there are no studies comparing the efficacy of these drugs in randomized clinical trials. We therefore suggest, for greater efficacy, using the available option, as soon as possible after the onset of the attack. 


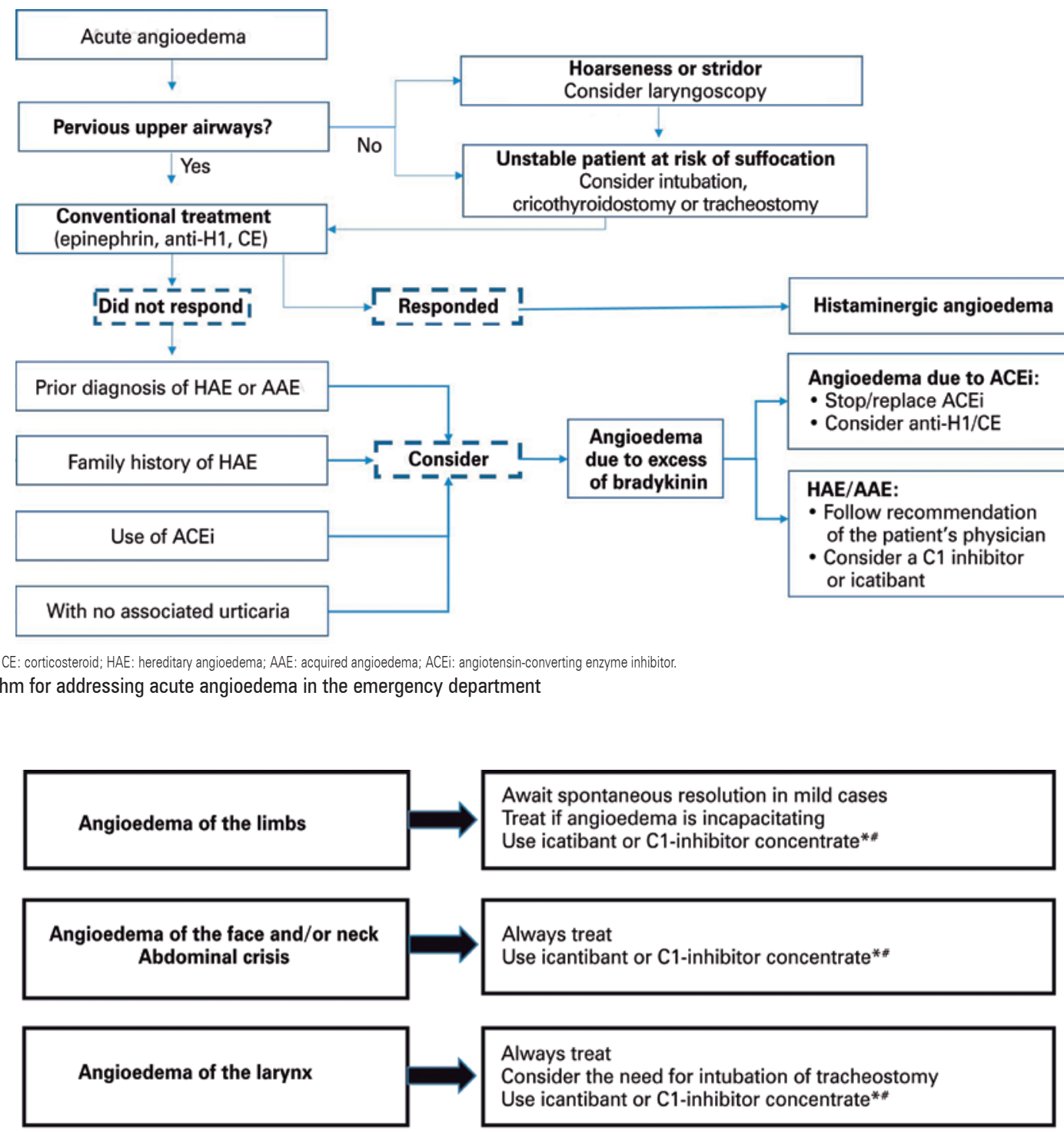

*Available in Brazil: C1-inhibitor concentrate (Berinert ${ }^{8}$ ) and icatibant (Firazyr ${ }^{8}$ ): * in all situations, if C1-inhibitor concentrate or icatibant is not available, use fresh frozen plasma.

Figure 4. Recommendations for treatment of hereditary angioedema attack, according to the affected area

Table 3. Characteristics and guidelines for the drugs available in Brazil for attacks

\begin{tabular}{|c|c|c|}
\hline \multirow{2}{*}{ Characteristics/guidelines } & \multicolumn{2}{|c|}{ Drug } \\
\hline & Icatibant $\left(\right.$ Firazyr $\left.^{\circledR}\right)$ & C1-INH concentrate $\left(\right.$ Berinert $^{\circledR}$ ) \\
\hline Age range & $>2$ years & No age limit \\
\hline Formulation & $10 \mathrm{mg} / \mathrm{mL}$ of icatibant (syringe with $3 \mathrm{~mL}$ of the solution) & $500 \mathrm{IU}$ of C1-INH in freeze-dried powder \\
\hline Dose & $\begin{array}{c}0.4 \mathrm{mg} / \mathrm{kg} \text { up to } 18 \text { years } \\
30 \mathrm{mg} \text { over } 18 \text { years }\end{array}$ & $201 \mathrm{U} / \mathrm{kg}$ \\
\hline Administration route & $\begin{array}{l}\text { Subcutaneous, slowly } \\
\text { Preferentially in the abdominal region }\end{array}$ & Slow intravenous or infusion (4mL/minute) \\
\hline Aspect of the solution & Colorless and clear & Colorless and limpid \\
\hline Storage temperature & $2^{\circ} \mathrm{C}$ to $8^{\circ} \mathrm{C}$ & $2^{\circ} \mathrm{C}$ to $8^{\circ} \mathrm{C}$ \\
\hline Storage after use of fractionated dose or reconstitution & $\begin{array}{l}\text { Not recommended } \\
\text { Under } 18 \text { years and weight of } 65 \mathrm{~kg} \text {; the unused volume } \\
\text { should be discarded }\end{array}$ & After reconstitution, exclusively in the ampoule flask \\
\hline Time of storage & Not recommended & Maximum of 8 hours at room temperature \\
\hline
\end{tabular}

Source: Brasil. Ministério da Saúde. Agência Nacional de Vigilância Sanitária (ANVISA). Bulário eletrônico. Firazyr: solução injetável. Bula profissional do medicamento. Brasilia (DF): ANVISA; 2019 [citado 2020 Jan 22 ]. Disponível em: https://consultas. anvisa.gov.br/\#/bulario/q/?nomeProduto=FIRAZYR; ${ }^{\mid 27}$ Brasil. Ministério da Saúde. Agência Nacional de Vigilância Sanitária (ANVISA). Bulário eletrônico. Berinert: pó liofilizado para solução injetável. Bula profissional do medicamento. Braślia (DF): ANVISA;2019 [citado 2020 Jan 22]. Disponivel em: https://consultas.anvisa.gov.br/\#/bulario/q/?nomeProduto=berinert'28]

C1-INH: C1-inhibitor. 
Another alternative, in use for many years, for C1INH replacement is the infusion of fresh frozen plasma, two to four units for adults, and $10 \mathrm{~mL}$ per $\mathrm{kg}$, for children. However, this strategy has not yet been tested for efficacy and safety in in HAE in clinical trials and should be reserved for situations in which no other drug for attacks is available. ${ }^{(1)}$ In addition, plasma administration offers not only C1-INH replacement, but also the substrates on which this inhibitor acts, and may not have adequate efficacy and even aggravate the condition.

\section{Treatment of hereditary angioedema attack in special situations Children and adolescents}

To date, few strategies have been licensed for use in the pediatric population. In Brazil, Berinert ${ }^{\circledR}$ is approved, without age restriction, at a dose of $201 \mathrm{IU} / \mathrm{kg}$, and icatibant has been recently approved for use as of 2 years of age. ${ }^{(37,38)}$

\section{Pregnancy, childbirth, postpartum and lactation}

There are few studies on the safety and efficacy of drugs for treating attacks during pregnancy, puerperium, and lactation. The treatment of choice during pregnancy, childbirth, postpartum, and breastfeeding is the pdC1INH concentrate. ${ }^{(39)}$ When pdC1-INH concentrate is not available, fresh frozen plasma can be administered. (39)

Icatibant $\left(\right.$ Firazyr $\left.^{\circledR}\right)$ and pdC1-INH concentrate (Berinert ${ }^{\circledR}$ ) are classified as Category $\mathrm{C}$ by the Food and Drug Administration (FDA) for use in pregnancy and lactation. However, these drugs have been used during pregnancy in situations of neccessity, proving to be effective and safe, with no adverse effect for pregnant women and neonates. ${ }^{(40)}$

Patients seen in the emergency department with suspected HAE should be referred to a specialist for investigation. Cases with confirmed diagnosis should be guided as to the need for regular specialized followup to identify possible triggers of attacks. They should also be evaluated as to the need for long-term and short-term prophylactic treatment (invasive diagnostic procedures, surgeries, and dental treatments). Some drugs used for treatment of attacks can also be used in prophylaxis, such as pdC1-INH concentrate. Recently, an immunobiological agent has been approved that blocks kallikrein, and consequent bradykinin formation, indicated for long-term prophylaxis. ${ }^{(41)}$ (Table 4).

Table 4. Drugs for short- and long-term prophylaxis used in the treatment of hereditary angioedema

\begin{tabular}{|c|c|c|c|c|c|c|}
\hline Drug & Brand name & Mechanism of action & Indication & Dosage (prophylaxis) & $\begin{array}{c}\text { Administration } \\
\text { route }\end{array}$ & Side effects \\
\hline Tranexamic acid & $\begin{array}{c}\text { Generic, } \\
\text { Hemoblock }^{\circledR} \text { and } \\
\text { Transamin }^{\circledR}\end{array}$ & Antifibrinolytic action & $\begin{array}{l}\text { Long-term } \\
\text { prophylaxis } \\
\text { Short-term } \\
\text { prophylaxis }\end{array}$ & $\begin{array}{c}20-50 \mathrm{mg} / \mathrm{kg} / \mathrm{day} \text { ( } 2-3 \text { times/day) up to } \\
4-6 \mathrm{~g} / \mathrm{day} \text {; pills=250mg } \\
25 \mathrm{mg} / \mathrm{kg} / \text { day (maximum dose } \\
3-6 \mathrm{~g} / \mathrm{day}), 5 \text { days before and } \\
2-5 \text { days after the procedure }\end{array}$ & Oral & $\begin{array}{l}\text { Muscle pain, weakness, } \\
\text { elevated CPK, nausea, } \\
\text { diarrhea, vertigo, postural } \\
\text { hypotension, severe } \\
\text { fatigue and thrombosis }\end{array}$ \\
\hline Danazol & 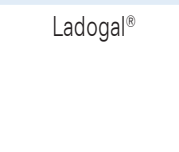 & $\begin{array}{l}\text { Attenuated androgen; } \\
\text { increases levels of C1-INH }\end{array}$ & $\begin{array}{l}\text { Long-term } \\
\text { prophylaxis } \\
\text { Short-term } \\
\text { prophylaxis }\end{array}$ & $\begin{array}{l}\text { Up to } 200 \mathrm{mg} / \text { day } \\
10 \mathrm{mg} / \mathrm{kg} / \text { day (maximum dose of } \\
600 \mathrm{mg} / \mathrm{day} \text { ), for } 5-7 \text { days before } \\
2 \text { days after the procedure }\end{array}$ & Oral & \multirow{2}{*}{$\begin{array}{c}\text { Weight gain, headache, } \\
\text { menstrual abnormalities, } \\
\text { acne, libido modification, } \\
\text { anxiety, mood disorders, } \\
\text { hypertension, myopathy, } \\
\text { changes in lipid profile, } \\
\text { hematuria, hepatoma and } \\
\text { hepatocarcinoma }\end{array}$} \\
\hline Oxandrolone & Compounded & $\begin{array}{l}\text { Attenuated androgen; } \\
\text { increases the levels of } \\
\text { C1-INH }\end{array}$ & $\begin{array}{l}\text { Long-term } \\
\text { prophylaxis }\end{array}$ & $\begin{array}{c}\text { Up to } 2.5 \mathrm{mg} \text {, every } 8-12 \text { hours, up to } \\
20 \mathrm{mg} / \mathrm{day} \\
\text { Child: } 0.25 \mathrm{mg} / \mathrm{kg} / \mathrm{day}\end{array}$ & Oral & \\
\hline $\begin{array}{l}\mathrm{pdC1}-\mathrm{INH}^{*} \\
\text { concentrate }\end{array}$ & Cinryze ${ }^{\oplus+}$ & C1-INH replacement & $\begin{array}{l}\text { Long-term } \\
\text { prophylaxis } \\
\text { Short-term } \\
\text { prophylaxis }\end{array}$ & $\begin{array}{l}1,000 \mathrm{IU}, \text { every } 3-4 \text { days } \\
500-1,000 \mathrm{IU} \text { before the procedure }\end{array}$ & Intravenous & \multirow[t]{2}{*}{$\begin{array}{l}\text { Thrombotic events were } \\
\text { observed in some patients }\end{array}$} \\
\hline $\begin{array}{l}\mathrm{pdC1}-\mathrm{INH}^{*} \\
\text { concentrate }\end{array}$ & Berinert $^{\circledR \ddagger}$ & C1-INH replacement & $\begin{array}{l}\text { Long-term } \\
\text { prophylaxis } \\
\text { Short-term } \\
\text { prophylaxis }\end{array}$ & $\begin{array}{c}20 \mid \mathrm{IU} / \mathrm{kg} \text {, every } 3-4 \text { days } \\
20 \mathrm{IU} / \mathrm{kg} \text { or } 500-1,000 \mathrm{IU} \text { before the } \\
\text { procedure }\end{array}$ & Intravenous & \\
\hline Lanadelumab & Thakzyro ${ }^{\circledast}$ & Kallikrein inhibitor & $\begin{array}{l}\text { Long-term } \\
\text { prophylaxis }\end{array}$ & $300 \mathrm{mg}$ every 4 weeks & Subcutaneous & $\begin{array}{l}\text { Injection site reactions, } \\
\text { hypersensitivity, dizziness, } \\
\text { maculopapular eruption, } \\
\text { myalgia and hepatic } \\
\text { enzyme modifications }\end{array}$ \\
\hline
\end{tabular}

Source: adapted from Giavina-Bianchi P, Arruda LK, Aun MV, Campos RA, Chong-Neto HJ, Constantino-Silva RN, et al. Diretrizes brasileiras para o diagnóstico e tratamento do angioedema hereditário - 2017. Arq Asma Alerg Imunol. 2017;1(1):23-48.11 ${ }^{*}$ Plasma-derived C1-INH concentrate; ${ }^{\dagger}$ Cinryzz ${ }^{\mathbb{E}}$ requires imports; ${ }^{\sharp}$ Berinert ${ }^{\mathbb{E}}$ was approved only for treatment of acute attacks in the United States and in Brazil; ${ }^{\circledR}$ Lanadelumab is a monoclonal antibody $($ lgG anti-kallikrein)

CPK: creatine phosphokinase; $\mathrm{C} 1$-INH: $\mathrm{C} 1$ inhibitor. 


\section{- CONCLUSION}

Hereditary angioedema attacks are unusual causes of angioedema in the emergency department. Restricted knowledge of hereditary angioedema by healthcare professionals can lead to incorrect diagnoses, especially when these attacks manifest in internal organs. Although rare, due to its potential for fatality, physicians acting in the emergency department should be aware of the warning signs of hereditary angioedema, especially when there is no response to treatment with usual drugs, such as antihistamines and corticosteroids. The correct and immediate management of these patients prevents unnecessary surgeries and, above all, fatal outcomes.

\section{AUTHORS' INFORMATION}

Serpa FS: http://orcid.org/0000-0002-5703-4370

Mansour E: http://orcid.org/0000-0001-6450-6930

Aun MV: http://orcid.org/0000-0001-9882-5200

Giavina-Bianchi P: http://orcid.org/0000-0002-1034-7580

Chong Neto HJ: http://orcid.org/0000-0002-7960-3925

Arruda LK: http://orcid.org/0000-0002-7505-210X

Campos RA: http://orcid.org/0000-0001-9524-761X

Motta AA: http://orcid.org/0000-0003-0276-3362

Toledo E: http://orcid.org/0000-0002-7454-8541

Grumach AS: http://orcid.org/0000-0002-9803-0309

Valle SO: http://orcid.org/0000-0001-5512-7349

\section{REFERENCES}

1. Giavina-Bianchi P, Arruda LK, Aun MV, Campos RA, Chong-Neto HJ, Constantino-Silva RN, et al. Diretrizes brasileiras para o diagnóstico e tratamento do angioedema hereditário - 2017. Arq Asma Alerg Imunol. 2017;1(1):23-48.

2. Depetri F, Tedeschi A, Cugno M. Angioedema and emergency medicine: from pathophysiology to diagnosis and treatment. Eur J Intern Med. 2019;59:8-13. Review.

3. Bernstein JA, Cremonesi P, Hoffmann TK, Hollingsworth J. Angioedema in the emergency department: a practical guide to differential diagnosis and management. Int J Emerg Med. 2017;10(1):15. Review.

4. Pedrosa M, Prieto-García A, Sala-Cunill A; Spanish Group for the Study of Bradykinin-Mediated Angioedema (SGBA) and the Spanish Committee of Cutaneous Allergy (CCA). Management of angioedema without urticaria in the emergency department. Ann Med. 2014;46(8):607-18. Review.

5. Bork K, Hardt J, Witzke G. Fatal laryngeal attacks and mortality in hereditary angioedema due to C1-INH deficiency. J Allergy Clin Immunol. 2012; 130(3):692-7.

6. Rubinstein E, Stolz LE, Sheffer AL, Stevens C, Bousvaros A. Abdominal attacks and treatment in hereditary angioedema with $\mathrm{C} 1$-inhibitor deficiency. BMC Gastroenterol. 2014;14:71

7. Abdon Barbosa A, de Oliveira Martins R, Martins R, Grumach AS. Assessment on hereditary angioedema burden of illness in Brazil: a patient perspective. Allergy Asthma Proc. 2019;40(3):193-7.

8. Kelly M, Donnelly JP, McAnnally JR, Wang HE. National estimates of emergency department visits for angioedema and allergic reactions in the United States. Allergy Asthma Proc. 2013;34(2):150-4.

9. Bertazzoni G, Spina MT, Scarpellini MG, Buccelletti F, De Simone M, Gregori M, et al. Drug-induced angioedema: experience of Italian emergency departments. Intern Emerg Med. 2014;9(4):455-62.
10. Felder S, Curtis RM, Ball I, Borici-Mazi R. Prognostic factors in outcome of angioedema in the emergency department. Allergy Asthma Proc. 2014; 35(5):362-70.

11. Zuberbier T, Aberer W, Asero R, Abdul Latiff AH, Baker D, Ballmer-Weber $B$, Bernstein JA, Bindslev-Jensen C, Brzoza Z, Buense Bedrikow R, Canonica GW, Church MK, Craig T, Danilycheva IV, Dressler C, Ensina LF, GiménezArnau A, Godse K, Gonçalo M, Grattan C, Hebert J, Hide M, Kaplan A, Kapp A, Katelaris CH, Kocatürk E, Kulthanan $\mathrm{K}$, Larenas-Linnemann D, Leslie TA, Magerl M, Mathelier-Fusade P, Meshkova RY, Metz M, Nast A, Nettis E, OudeElberink H, Rosumeck S, Saini SS, Sánchez-Borges M, Schmid-Grendelmeier P, Staubach P, Sussman G, Toubi E, Vena GA, Vestergaard C, Wedi B, Werner RN, Zhao Z, Maurer $M$; Endorsed by the following societies: AAAAI, AAD, AAIITO, ACAAI, AEDV, APAAACI, ASBAI, ASCIA, BAD, BSACI, CDA, CMICA, CSACl, DDG, DDS, DGAKI, DSA, DST, EAACl, EIAS, EDF, EMBRN, ESCD, GA2LEN, IAACI, IADVL, JDA, NVVA, MSAI, ÖGDV, PSA, RAACI, SBD, SFD, SGAI, SGDV, SIAAIC, SIDeMaST, SPDV, TSD, UNBB, UNEV and WAO. The AACI/GA2LEN/EDF/WAO guideline for the definition, classification, diagnosis and management of urticaria. Allergy. 2018;73(7):1393-1414.

12. Cicardi M, Aberer W, Banerji A, Bas M, Bernstein JA, Bork K, et al. HAWK under the patronage of EAACI (European Academy of Allergy and Clinical Immunology). Classification, diagnosis, and approach to treatment for angioedema: consensus report from the Hereditary Angioedema International Working Group. Allergy. 2014;69(5):602-16.

13. Bafunno V, Firinu D, D’Apolito M, Cordisco G, Loffredo S, Leccese A, et al. Mutation of the angiopoietin-1 gene (ANGPT1) associates with a new type of hereditary angioedema. J Allergy Clin Immunol. 2018;141(3):1009-17.

14. Bok K, Wulff K, Witzke G, Hardt J. Hereditary angioedema with normal C1-INH with versus without specific F12 gene mutations. Allergy. 2015;70(8):1004-12.

15. Bork K, Wulff K, Steinmüller-Magin L, Braenne I, Staubach-Renz P, Witzke $\mathrm{G}$, et al. Hereditary angioedema with a mutation in the plasminogen gene. Allergy. 2018;73(2):442-50. Erratum in: Allergy. 2018;73(12):2412.

16. Bork K, Wulff K, Rossmann H, Steinmüller-Magin L, Braenne I, Witzke G, et al. Hereditary angioedema cosegregating with a novel kininogen 1 gene mutation changing the N-terminal cleavage site of bradykinin. Allergy. 2019; 74(12):2479-81.

17. Jaiganesh $T$, Wiese M, Hollingsworth J, Hughan C, Kamara M, Wood $P$, et al. Acute angioedema: recognition and management in the emergency department. Eur J Emerg Med. 2013;20(1):10-7. Review.

18. Banerji A, Blumenthal KG, Lai KH, Zhou L. Epidemiology of ACE inhibitor angioedema utilizing a large electronic health record. J Allergy Clin Immunol Pract. 2017;5(3):744-9.

19. Scott SI, Andersen MF, Aagaard L, Buchwald CV, Rasmussen ER. Dipeptidyl peptidase-4 inhibitor induced angioedema - an overlooked adverse drug reaction? Curr Diabetes Rev. 2018;14(4):327-33. Review.

20. Aygören-Pürsün E, Magerl M, Maetzel A, Maurer M. Epidemiology of Bradykinin-mediated angioedema: a systematic investigation of epidemiological studies. Orphanet J Rare Dis. 2018;13(1):73.

21. Moellman JJ, Bernstein JA, Lindsell C, Banerji A, Busse PJ, Camargo CA Jr, Collins SP, Craig TJ, Lumry WR, Nowak R, Pines JM, Raja AS, Riedl M, Ward MJ, Zuraw BL, Diercks D, Hiestand B, Campbell RL, Schneider S, Sinert R; American College of Allergy, Asthma \& Immunology (ACAAI); Society for Academic Emergency Medicine (SAEM). A consensus parameter for the evaluation and management of angioedema in the emergency department. Acad Emerg Med. 2014;21(4):469-84.

22. Kaplan AP, Joseph K. Pathogenesis of hereditary angioedema: the role of the bradykinin-forming cascade. Immunol Allergy Clin North Am. 2017;37(3):513-25. Review.

23. Grumach AS, Ferraroni N, Olivares MM, López-Serrano MC, Bygum A An $A B C$ of the warning signs of hereditary angioedema. Int Arch Allergy Immunol. 2017;174(1):1-6. Review.

24. Craig T, Aygören- Pürsün E, Bork K, Bowen T, Boysen H, Farkas H, et al. WAO Guideline for the Management of Hereditary Angioedema. World Allergy Organ J. 2012;5(12):182-99.

25. Cicardi M, Bellis P, Bertazzoni G, Cancian M, Chiesa $M$, Cremonesi $P$, et al. Guidance for diagnosis and treatment of acute angioedema in the emergency department: consensus statement by a panel of Italian experts. Intern Emerg Med. 2014;9(1):85-92. 
26. Riedl MA, Bernstein JA, Li H, Reshef A, Lumry W, Moldovan D, et al. Recombinant human $\mathrm{C} 1$-esterase inhibitor relieves symptoms of hereditary angioedema attacks: phase 3, randomized, placebo-controlled trial. Ann Allergy Asthma Immunol. 2014;112(2):163-9.

27. Brasil. Ministério da Saúde. Agência Nacional de Vigilância Sanitária (ANVISA). Bulário eletrônico. Firazyr: solução injetável. Bula profissional do medicamento. Brasília (DF): ANVISA; 2019 [citado 2020 Jan 22]. Disponível em: https://consultas.anvisa.gov.br/\#/bulario/q/?nomeProduto = FIRAZYR

28. Brasil. Ministério da Saúde. Agência Nacional de Vigilância Sanitária (ANVISA). Bulário eletrônico. Berinert: pó liofilizado para solução injetável. Bula profissional do medicamento. Brasília (DF): ANVISA;2019 [citado 2020 Jan 22]. Disponível em: https://consultas.anvisa.gov.br/\#/bulario/q/?nomeProduto= berinert

29. Craig TJ, Bewtra AK, Bahna SL, Hurewitz D, Schneider LC, Levy RJ, et al. C1 esterase inhibitor concentrate in 1085 hereditary angioedema attacks - final results of the I.M.P.A.C.T.2 study. Allergy. 2011;66(12):1604-11.

30. Bork K. Pasteurized and nanofiltered, plasma-derived C1 esterase inhibitor concentrate for the treatment of hereditary angioedema. Immunotherapy. 2014;6(5):533-51. Review.

31. Bork K, Bernstein JA, Machnig T, Craig TJ. Efficacy of different medical therapies for the treatment of acute laryngeal attacks of hereditary angioedema due to C1-esterase inhibitor deficiency. J Emerg Med. 2016; 50(4):567-80. Review.

32. Cicardi M, Banerji A, Bracho F, Malbrán A, Rosenkranz B, Riedl M, et al. Icatibant, a new bradykinin-receptor antagonist, in hereditary angioedema. N Engl J Med. 2010;363(6):532-41. Erratum in: N Engl J Med. 2010; 363(15):1486.

33. Lumry WR, Li HH, Levy RJ, Potter PC, Farkas H, Moldovan D, et al. Randomized placebo-controlled trial of the bradykinin $B_{2}$ receptor antagonist icatibant for the treatment of acute attacks of hereditary angioedema: the FAST-3 trial. Ann Allergy Asthma Immunol. 2011;107(6):529-37.
34. Maurer M, Aberer W, Bouillet L, Caballero T, Fabien V, Kanny G, Kaplan A Longhurst $\mathrm{H}$, Zanichelli $\mathrm{A} ; \mathrm{I} O \mathrm{~S}$ Investigators. Hereditary angioedema attacks resolve faster and are shorter after early icatibant treatment. PLoS One. 2013;8(2):e53773.

35. Aberer W, Maurer M, Reshef A, Longhurst H, Kivity S, Bygum A, et al. Open-label, multicenter study of self-administered icatibant for attacks of hereditary angioedema. Allergy. 2014;69(3):305-14.

36. Cicardi M, Levy RJ, McNeil DL, Li HH, Sheffer AL, Campion M, et al. Ecallantide for the treatment of acute attacks in hereditary angioedema. N Engl J Med. 2010;363(6):523-31.

37. Frank MM, Zuraw B, Banerji A, Bernstein JA, Craig T, Busse $P$, et al. Management of children with hereditary angioedema due to $\mathrm{C} 1$ inhibitor deficiency. Pediatrics. 2016;138(5):e20160575.

38. Farkas $H$, Reshef A, Aberer W, Caballero T, McCarthy L, Hao J, et al. Treatment effect and safety of icatibant in pediatric patients with hereditary angioedema. J Allergy Clin Immunol Pract. 2017;5(6):1671-8.e2.

39. Caballero T, Farkas H, Bouillet L, Bowen T, Gompel A, Fagerberg C, Bjökander J, Bork K, Bygum A, Cicardi M, de Carolis C, Frank M, Gooi JH, Longhurst H, Martínez-Saguer I, Nielsen EW, Obtulowitz K, Perricone R, Prior N; C-1-INH Deficiency Working Group. International consensus and practical guidelines on the gynecologic and obstetric management of female patients with hereditary angioedema caused by $\mathrm{C} 1$ inhibitor deficiency. J Allergy Clin Immunol. 2012;129(2):308-20.

40. Hakl R, Kuklínek $P$, Krčmová I, Králičková $P$, Freiberger $T$, Janků $P$, et al. Treatment of hereditary angioedema attacks with icatibant and recombinant C1 Inhibitor During Pregnancy. J Clin Immunol. 2018;38(7):810-5.

41. Bova M, Valerieva A, Wu MA, Senter R, Perego F. Lanadelumab injection treatment for the prevention of hereditary angioedema (HAE): design, development and place in therapy. Drug Des Devel Ther. 2019;13:3635-46. Review. 